\title{
PULPOTOMIES WITH PORTLAND CEMENT IN HUMAN PRIMARY MOLARS
}

\author{
Taísa Regina CONTI ${ }^{1}$, Vivien Thiemy SAKAI ${ }^{2}$, Ana Paula Camolese FORNETTI ${ }^{2}$, Ana Beatriz Silveira MORETTI ${ }^{3}$, \\ Thais Marchini OLIVEIRA ${ }^{3}$, Natalino LOURENÇO NETO ${ }^{2}$, Maria Aparecida Andrade Moreira MACHADO ${ }^{4}$, \\ Ruy Cesar Camargo ABDO $^{4}$
}

1- Undergraduate Student, Bauru School of Dentistry, University of São Paulo, Bauru, SP, Brazil.

2- DDS, MSc, Department of Pediatric Dentistry, Orthodontics and Community Health, Bauru School of Dentistry, University of São Paulo, Bauru, SP, Brazil. 3- DDS, PhD, Department of Pediatric Dentistry, Orthodontics and Community Health, Bauru School of Dentistry, University of São Paulo, Bauru, SP, Brazil. 4- DDS, PhD, Professor, Department of Pediatric Dentistry, Orthodontics and Community Health, Bauru School of Dentistry, University of São Paulo, Bauru, SP, Brazil.

Corresponding address: VivienThiemy Sakai - FOB/USP - Alameda Dr. Octávio Pinheiro Brisolla, 9-75 - 17012-901 - Bauru, SP - Brasil - Phone: +5514-3235-8218 - Fax: +55-14-3223-4679 - e-mail: viviensakai@usp.br

Received: June 4, 2008 - Modification: August 31, 2008 - Accepted: September 9, 2008

\begin{abstract}
$T$

wo clinical cases in which Portland cement (PC) was applied as a medicament after pulpotomy of mandibular primary molars in children are presented. Pulpotomy using PC was carried out in two mandibular first molars and one mandibular second molar, which were further followed-up. At the 3, 6 and 12-month follow-up appointments, clinical and radiographic examinations of the pulpotomized teeth and their periradicular area revealed that the treatments were successful in maintaining the teeth asymptomatic and preserving pulpal vitality. Additionally, the formation of a dentin bridge immediately below the PC could be observed in the three molars treated. PC may be considered as an effective alternative for primary molar pulpotomies, at least in a short-term period. Randomized clinical trials with human teeth are required in order to determine the suitability of PC before unlimited clinical use can be recommended.
\end{abstract}

Key words: Mineral Trioxide Aggregate. Portland cement. Primary teeth. Pulpotomy.

\section{INTRODUCTION}

Pulpotomy is the most widely accepted clinical procedure for treating primary teeth with inflammation of the coronal pulp caused by caries with no involvement of the radicular pulp. This technique consists of removing the coronal pulp and healing the radicular pulp with a medicament. The purpose is to remove the bacterial infection leaving the treated tooth asymptomatic until its exfoliation ${ }^{13,24}$.

Medicaments applied to radicular pulp tissue after pulpotomy have included formocresol ${ }^{1,13}$, ferric sulphate ${ }^{13}$, calcium hydroxide ${ }^{30}$, and mineral trioxide aggregate (MTA $)^{1,2,4,12,22,23,28}$. Recently, great interest has been focused on the evolution of Portland cement (PC) as an alternative to MTA, and several studies have compared both materials ${ }^{3 \text {, }}$ $6,8,9,11,15-17,31$

PC differs from MTA by the absence of bismuth ions $\mathrm{s}^{5,11,18,26}$ and the presence of potassium ions ${ }^{25}$. Both materials have comparable antibacterial activity ${ }^{11}$ and almost identical properties macroscopically, microscopically and by X-ray diffraction analysis ${ }^{16,26,31}$. It has also been shown that PC and MTA have similar effect on pulpal cells when used for direct pulp capping in rat teeth ${ }^{31}$. Holland, et al. ${ }^{16}$ studied the rat subcutaneous connective tissue response to implanted dentin tubes filled with MTA, PC and calcium hydroxide and found very similar mechanisms of action. In addition, both MTA and PC allowed for dentin bridge formation after pulpotomy was performed in $\operatorname{dog} \mathrm{s}^{15}$. Finally, Min, et al. ${ }^{21}$ observed that PC allowed the expression of mRNAs of a dentin-specific protein and a noncollagenous protein involved in mineralization in cultured human pulp cells.

Taking into account the low cost and apparently similar properties of $\mathrm{PC}$ in comparison to MTA, it is reasonable to consider PC as a possible substitute for MTA in endodontic applications $s^{9,10,20,25,31}$. Therefore, this paper presents two clinical cases in which PC was applied as a medicament after pulpotomy of mandibular primary molars in children. 


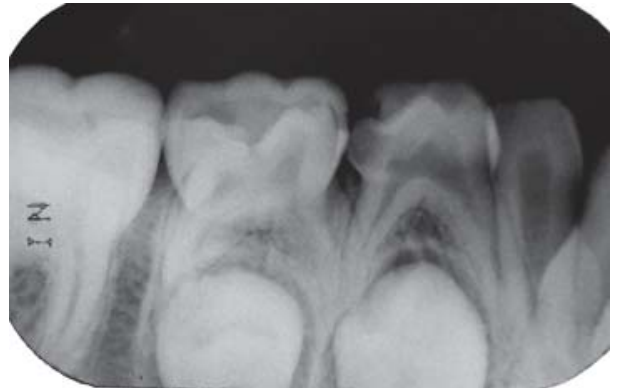

FIGURE 1A- Preoperative periapical radiograph of the mandibular right primary first molar of a 7-year old boy, which presented an extensive caries lesion, more than two thirds of root length and no signs of periapical lesion

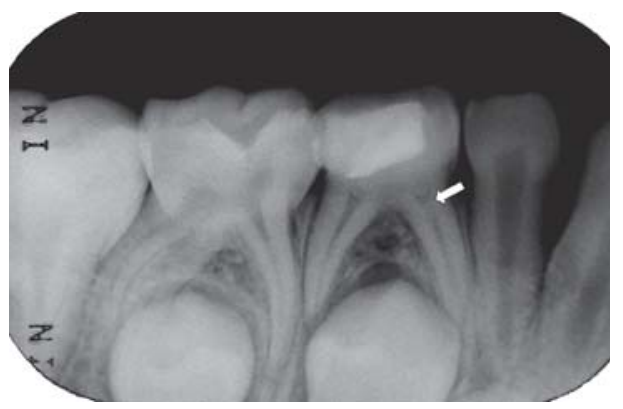

FIGURE 1B- 3-month follow-up periapical radiograph suggesting the initial formation of a dentin bridge immediately below the Portland cement in the mesial root (arrow) and absence of periapical lesion in the pulpotomized mandibular right primary first molar

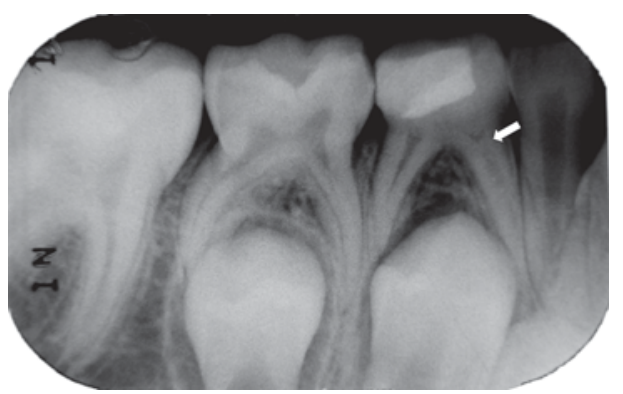

FIGURE 1C- 6-month follow-up periapical radiograph suggesting the presence of the dentin bridge immediately below the Portland cement in the mesial root (arrow) of the pulpotomized mandibular right primary first molar

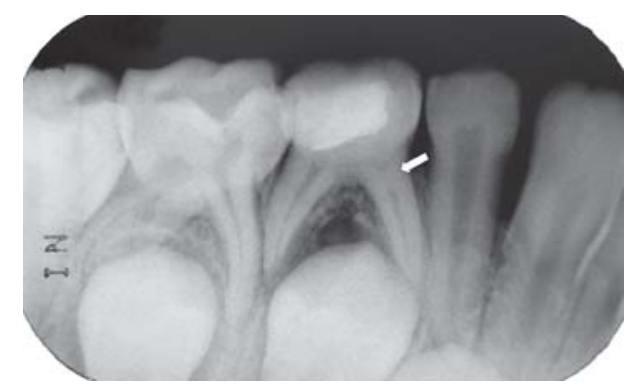

FIGURE 1D- 12-month follow-up periapical radiograph suggesting the presence of the dentin bridge immediately below the Portland cement in the mesial root (arrow) of the pulpotomized mandibular right primary first molar

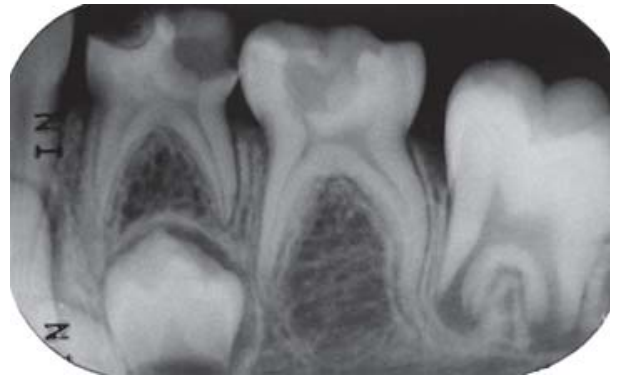

FIGURE 2A- Preoperative periapical radiograph of the mandibular left primary molars of a 6-year old girl, which presented extensive caries lesions, two thirds or more of root length, and no signs of periapical lesion. Agenesis of the mandibular left permanent second premolar was observed

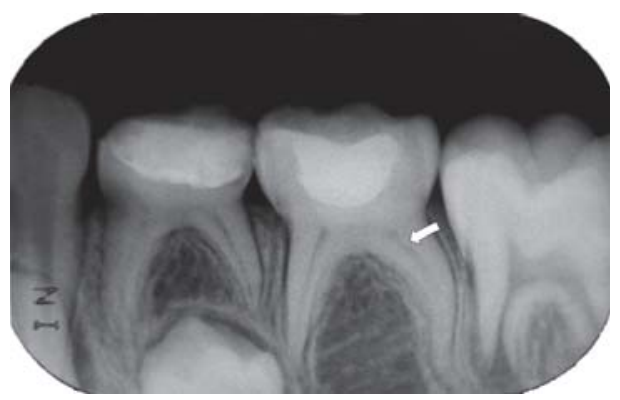

FIGURE 2B-3-month follow-up periapical radiograph suggesting the initial formation of a dentin bridge immediately below the Portland cement in the distal root (arrow) of the pulpotomized mandibular left second molar and absence of periapical lesion in both pulpotomized mandibular left primary molars

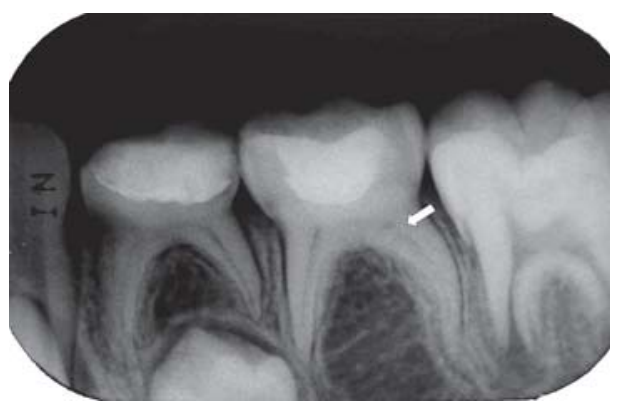

FIGURE 2C- 6-month follow-up periapical radiograph suggesting the presence of the dentin bridge immediately the Portland cement in the distal root (arrow) of the pulpotomized mandibular left second molar

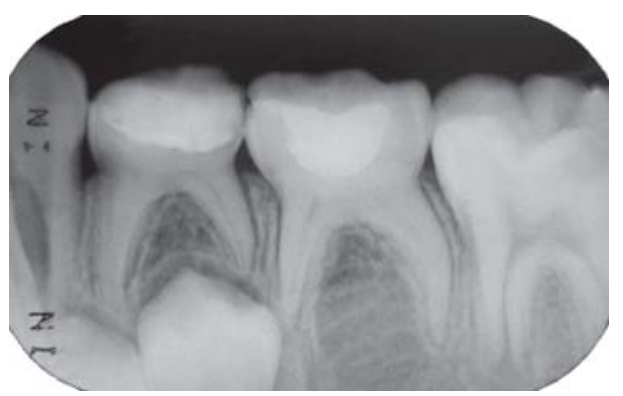

FIGURE 2D- 12-month follow-up periapical radiograph suggesting the initial radicular pulp obliteration of the mandibular right primary first molar 


\section{CASE REPORTS}

A 7-year old boy and a 6-year old girl were referred to our institution with a request for dental care because of the presence of caries lesion. They had no systemic pathology or known allergies to latex, topical or local anesthetics or to the compounds from which PC is made. The following findings were observed in mandibular primary molars: need for a pulpotomy treatment due to caries; no previous treatment; no signs of radicular pulp degeneration (abscesses of associated fistulous tracts); no radiographic signs of furcation involvement, internal or external pathological root resorption, or pathological thickening of the periodontal membrane; no increased mobility; two thirds or more of root length and possibility of restoration using resin modified glass ionomer cement ${ }^{19}$ (Figures 1a and $2 \mathrm{a}$ ).

The pulpotomy procedure using PC was carried out on two mandibular first molars and one mandibular second molar. Although one could consider a risk the use PC in humans, it is worth mentioning that its use was assessed by Brazilian Health Ministry and further approved by the Research Ethics Committee of the Bauru School of Dentistry, University of São Paulo (Protocol \# 34/2005), thus validating the execution of the present clinical cases in human primary teeth.

In both cases, rubber dam isolation was used. Under local anesthesia, the teeth were excavated using handpiece with a bud bur. The opening of the pulp chambers was conducted with carbide bur, followed by irrigation with saline solution. The coronal pulp tissues were removed manually with an excavator. Drying and controlled bleeding of the remaining pulp tissues were obtained using slight pressure with a sterile cotton pellet, and then PC (Votorantim-Cimentos, São Paulo, SP, Brazil) was used. $0.16 \mathrm{~g}$ of PC was previously sterilized with ethylene oxide, mixed with sterile water to produce a homogenous paste and applied into the pulp chambers with a spatula. A layer of reinforced zinc oxide-eugenol (IRM ${ }^{\circledR}$; Dentsply Ind. e Com. Ltda, Petrópolis, RJ, Brazil) was placed prior to restoration with resin modified glass ionomer cement (Vitremer $^{\circledR}, 3 \mathrm{M} / \mathrm{ESPE}$, St. Paul, MN, USA). Immediate postoperative radiographs were taken.

Periodic follow-up examinations were carried out 3 (Figures $1 \mathrm{~b}$ and 2b), 6 (Figures $1 \mathrm{c}$ and 2c) and 12 months (Figures 1d and 2d) after the end of the treatment. Each checkup involved a clinical and radiographic examination of the pulpotomized teeth and their periradicular area, revealing that the treatments were successful in maintaining the teeth asymptomatic and preserving pulpal vitality. Additionally, the radiographic examinations revealed formation of a bridge, presumably dentin, immediately below the PC in the three molars treated.

The patients will be monitored quarterly in order to followup the pulpotomized molars and the eruption of all permanent teeth.

\section{DISCUSSION}

Several studies have reported excellent results when using MTA in endodontic treatments ${ }^{1,2,12,19,20,22,23,28,29}$. The factor responsible for the beneficial effects in MTA is also found in $\mathrm{PC}^{27}$. This has resulted in a significant body of research that shows that PC appears to be a useful substitute for MTA $^{9,10,20,25,27,31}$. However, only four studies reported the use of PC in conservative pulp therapy with considerable success in rats ${ }^{31}$ and $\operatorname{dogs} s^{15,17,20}$. In humans, there is only one work showing the use of PC in order to create an apical plug in the root of an immature tooth ${ }^{7}$. To the best of our knowledge, the case reports presented here is the first to describe the use of $\mathrm{PC}$ as a medicament after pulpotomy in human primary teeth.

After 3-month follow-up, a hard tissue barrier could be observed immediately below the PC, which was confirmed at the 6-month follow-up appointment. The ability of this material to induce the formation of a dentin bridge may be due to its mechanisms of action. $\mathrm{PC}$ has calcium oxide that forms calcium hydroxide when mixed with water. The reaction of the calcium from calcium hydroxide with the carbon dioxide from the pulp tissue produces calcite crystals. Then, a rich extracellular network of fibronectin in close contact with these crystals can be observed, strongly supporting the role of calcite crystals and fibronectin as an initiating step in the formation of a hard tissue barrier ${ }^{15}$. Moreover, PC has an excellent sealing ability and fast setting, thus preventing the diffusion of the material into the tissues, and reducing microleakage during the pulp healing period ${ }^{20}$.

Danesh, et al. ${ }^{6}$ showed that MTA displayed superior material properties than PC, which was significantly more soluble, reached lower microhardness values and was less radiopaque. The lack of radiopacity in pure $\mathrm{PC}$ is due to the absence of bismuth, a chemically inert radiopacifier, in its composition ${ }^{5}$. However, this feature does not compromise the execution of pulpotomy procedures with PC and their followup assessments, which is untrue when this material is used for root-end fillings. In these situations, a radiopacifier is necessary to enable the peri- and postoperative assessment of the cement placement reaching the end of the root.

A major concern regarding the use of water-based cements is the amount of leachable arsenic and lead present in the material. Arsenic and lead are impurities of limestone that is used in the manufacture of $\mathrm{PC}^{17}$. Duarte, et al. ${ }^{10}$ showed that the concentration of arsenic is low in PC and closely similar to that present in MTA, demonstrating no contraindication of the use of that material in clinical practice concerning the presence of this chemical element. However, no study has compared the lead content in these cements ${ }^{17}$.

In the cases presented here, the use of a stainless steel crown to restore the teeth was considered. Even though, a provisional and faster restoration with glass ionomer cement was chosen. Glass ionomer cement has good sealing properties and it is easy to handle $\mathrm{e}^{14,22}$. Adhesion properties of this material impart adequate retention even if mechanical undercuts are absent. Coverage of exposed dentin and sharp margins with glass ionomer cement to provide patient comfort is accomplished with minimal chair time ${ }^{14,22}$. It is important that 
the absence of evidence for glass ionomer cement should not be misinterpreted as evidence for its lack of efficacy.

The present cases revealed that PC may be considered as an effective and economic alternative medicament to formocresol and mineral trioxide aggregate for primary molar pulpotomies since the treated teeth were retained asymptomatic in the oral cavity and dentin barriers could be observed immediately below the material. Although our results are very encouraging, randomized clinical trials with human teeth need to be conducted in order to determine the suitability of PC before unlimited clinical use can be recommended.

\section{REFERENCES}

1 - Agamy HA, Bakry NS, Mounir MMF, Avery DR. Comparison of mineral trioxide aggregate and formocresol as pulp-capping agents in pulpotomized primary teeth. Pediatr Dent. 2004;26:302-9.

2 - Barrieshi-Nusair KM, Qudeimat MA. A prospective clinical study of mineral trioxide aggregate for partial pulpotomy in cariously exposed permanent teeth. J Endod. 2006;32:731-5.

3 - Bortoluzzi EA, Broon NJ, Bramante CM, Garcia RB, Moraes IG, Bernardineli N. Sealing ability of MTA and radiopaque Portland cement with or without calcium chloride for root-end filling. J Endod. 2006;32:897900 .

4 - Camilleri J, Pitt Ford TR. Mineral trioxide aggregate: a review of the constituents and biological properties of the material. Int Endod J. 2006;39:747-54

5 - Coomaraswamy KS, Lumley PJ, Hofmann MP. Effect of bismuth oxide radioopacifier content on the material properties of an endodontic Portland cement-based (MTA-like) system. J Endod. 2007;33:295-8.

6 - Danesh G, Dammaschke T, Gerth HUV, Zndbiglari T, Schafer E. A comparative study of selected properties of ProRoot mineral trioxide aggregate and two Portland cements. Int Endod J. 2006;39:213-9.

7 - De Deus G, Coutinho-Filho T. The use of white Portland cement as an apical plug in a tooth with a necrotic pulp and wide-open apex: a case report. Int Endod J. 2007;40:653-60.

8 - De Deus G, Petruccelli V, Gurgel-Filho E, Coutinho-Filho T. MTA versus Portland cement as repair material for furcal perforations: a laboratory study using polymicrobial leakage model. Int Endod J. 2006;39:293-8.

9 - De Deus G, Ximenes R, Gurgel-Filho ED, Plotkowski MC, CoutinhoFilho T. Cytotoxicity of MTA and Portland cement on human ECV 204 endothelial cells. Int Endod J. 2005;38:604-9.

10 - Duarte MAH, Demarchi ACCO, Yamashita JC, Kuga MC, Fraga SC. Arsenic release provided by MTA and Portland cement. Oral Surg Oral Med Oral Pathol Oral Radiol Endod. 2005;99:648-50.

11 - Estrela C, Bammann LL, Estrela CRA, Silva RS, Pécora JD. Antimicrobial and chemical study of MTA, Portland cement, calcium hydroxide paste, Sealapex and Dycal. Braz Dent J. 2000;11:19-27.

12 - Farsi N, Alamoudi N, Balto K, Mushayt A. Success of mineral trioxide aggregate in pulpotomized primary molars. J Clin Pediatr Dent. 2005;29:307-12.

13 - Fuks AB. Current concepts in vital primary pulp therapy. Eur J Paediatr Dent. 2002;3:115-20.
14 - Hewlett ER, Mount GJ. Glass ionomers in contemporary restorative dentistry - a clinical update. J Calif Dent Assoc. 2003;31:483-92.

15 - Holland R, Souza V, Murata SS, Nery MJ, Bernabé PF, Otoboni Filho JA, et al. Healing process of dog dental pulp after pulpotomy and pulp covering with mineral trioxide aggregate or Portland cement. Braz Dent J. 2001;12:109-13.

16 - Holland R, de Souza V, Nery MJ, Faraco IM Jr, Bernabé PF, Otoboni Filho JA, et al.. Reaction of rat connective tissue to implanted dentin tube filled with mineral trioxide aggregate, Portland cement or calcium hydroxide. Braz Dent J. 2001;12:3-8.

17 - Islam I, Chng HK, Yap AUJ. Comparison of the physical and mechanical properties of MTA and Portland cement. J Endod. 2006;32:193-7.

18 - Islam I, Chng HK, Yap AUJ. X-ray diffraction analysis of mineral trioxide aggregate and Portland cement. Int Endod J. 2006;39:220-5.

19 - Maroto M, Barbería E, Planells P, García-Godoy F. Dentin bridge formation after mineral trioxide aggregate (MTA) pulpotomies in primary teeth. Am J Dent. 2005;18:151-4.

20 - Menezes R, Bramante CM, Letra A, Carvalho VGG, Garcia RB. Histologic evaluation of pulpotomies in dog using two types of mineral trioxide aggregate and white Portland cements as wound dressings. Oral Surg Oral Med Oral Pathol Oral Radiol Endod. 2004;98:376-9.

21 - Min KS, Kim HI, Park HJ, Pi SH, Hong CU, Kim EC. Human pulp cells response to Portland cement in vitro. J Endod. 2007;33:163-6.

22 - Moretti ABS, Oliveira TM, Sakai VT, Santos CF, Machado MAAM, Abdo RCC. Mineral trioxide aggregate pulpotomy of a primary second molar in a patient with agenesis of the permanent successor. Int Endod J. 2007;40:738-45.

23 - Naik S, Hegde AM. Mineral trioxide aggregate as a pulpotomy agent in primary molars: an in vivo study. J Indian Soc Pedod Prev Dent. 2005;23:13-6

24 - Ranly D, García-Godoy F. Current and potential pulp therapies for primary and young permanent teeth. J Dent. 2000;28:153-61.

25 - Saidon J, He J, Zhu Q, Safavi K, Spangberg L. Cell and tissue reactions to mineral trioxide aggregate and Portland cement. Oral Surg Oral Med Oral Pathol Oral Radiol Endod. 2003;95:483-9.

26 - Song JS, Mante FK, Romanow WJ, Kim S. Chemical analysis of powder and set forms of Portland cement, gray ProRoot MTA, white ProRoot MTA, and gray MTA-Angelus. Oral Surg Oral Med Oral Pathol Oral Radiol Endod. 2006;102:809-15.

27 - Spangberg LSW. Response to letter to the editor by Carolyn M. Prismus, PhD. Oral Surg Oral Med Oral Pathol Oral Radiol Endod. 2006;101:418.

28 - Torabinejad M, Chivian N. Clinical applications of mineral trioxide aggregate. J Endod. 1999;25:197-205.

29 - Torabinejad M, Watson TF, Pitt Ford TR. Sealing ability of a mineral trioxide aggregate when used as a root end filling material. J Endod. 1993;19:591-5.

30 - Witherspoon DE, Small JC, Harris GZ. Mineral trioxide aggregate pulpotomies: a case series outcomes assessment. J Am Dent Assoc. 2006;137:610-8

31 - Wucherpfenning AL, Green DB. Mineral trioxide vs Portland cement: two biocompatible filling materials. J Endod. 1999;25:308. 